\title{
The Role Of Health Department Of Blora Regency In The Implementation Of Bpjs Based On Act No. 40 Of 2004 On The National Social Security System To Improve Health Service To The Society
}

\author{
Denny Kusuma ${ }^{1}$, Widayati ${ }^{2}$ and Siti Rodhiyah Dwi Istianah ${ }^{3}$
}

Abstract. The regional government through the Health Department became the backbone of the implementation of the national strategic program, including JKNKIS program. In various legislations such a role that includes licensing, facilitator, as well as giving recommendations and the availability of health facilities and the organization of health services for the implementation of the Health Insurance program. This study aims to determine the Role of Health Department of Blora Regency in the Implementation of BPJS Based On Act No. 40 of 2004 on National Social Security System to improve health services to the society and the obstacles that arise and solutions. The method used is the juridical sociological, descriptive analytical research specifications. The data used are primary data and secondary data, so that the method of collecting data through field studies and literature. Data analysis method used is qualitative analysis. As the blade is used the analysis of role theory and the theory of legal certainty. The results showed that the Role of Health Department of Blora Regency in the Implementation of BPJS Based On Act No. 40 of 2004 on National Social Security System to improve service to the public is as regulators, implementers and donors. The obstacles that arise in the implementation of BPJS in Blora is the increased fees but then disconnected MA which no increasing fees, any health facilities which can not service BPJS members because still not accredited the solution is that facilities apply a new accreditation to KARS, the role of Health Department in the implementation of BPJS not maximum so the solution is make a new regulation for empowerment the role of Health Department as regulator.

Keywords: Health Department; BPJS; National Social Security System; Health Services.

\section{Introduction}

Health is an important aspect in the life of the society, the government created an adequate health development as an improvement to a poor level of health over the years. Based on the Constitution of the Republic of Indonesia 1945 (Constitution of the Republic of Indonesia 1945) Article $28 \mathrm{H}$, establishes that health is a fundamental right of all individuals and all citizens are entitled to health care, including the poor. However, the increased health costs will complicate people's access to health care needs, especially when financing should be borne alone (out of pocket) in the system of fee for services. ${ }^{4}$

\footnotetext{
${ }^{1}$ Student of Master of Law, Faculty of Law, Sultan Agung Islamic University (UNISSULA), Semarang, email: dennykusuma666@gmail.com

${ }^{2}$ Lecturer of Master of Law, Sultan Agung Islamic University (UNISSULA), Semarang

${ }^{3}$ Lecturer of Master of Law, Sultan Agung Islamic University (UNISSULA), Semarang

${ }^{4}$ Yohandarwati dkk, 2003, Sistem Perlindungan dan jaminan Sosial (Suatu Kajian Awal), Bappenas, Jakarta, p.16.
} 
The government has sought to provide protection to citizens associated with health insurance through the policies that have been programmed. In 2004 issued Act No. 40 of the National Social Security System (Navigation). The law mandates that the compulsory social security for the entire population, including the National Health Insurance (JKN) through a Social Security Agency (BPJS).

January 1, 2014, the National Health Insurance System (JKN) held by the Social Security Organizing Body (BPJS) Health effectively starts. This system is basically an implementation of Act No. 40 of 2004 on National Social Security System (Navigation) which gave the mandate to the Government to carry out five social security, namely health insurance, accident insurance, old age insurance, pension insurance, and life insurance.

The Role of Local Government is expected to improve the quality of JKN-KIS program in accordance with the mandate of Act No. 40 of 2004 on National Social Security System. Currently local governments that integrate the health insurance program area (Jamkesda) into Program JKN-KIS has increased and is expected that all the local governments could do the same, in addition to many other things that can be done by local governments in support of implemented programs JKN-KIS that sustainable.

Local governments are becoming the backbone of the implementation of the national strategic program, including JKN-KIS program. Support and participation of the local government is crucial in optimizing JKN-KIS program, there are at least three important roles such as expanding the coverage, improve service quality, and increase the level of compliance. Local government can play a major role, especially in terms of member acceleration, improving access and quality of health services, financing affordable JKNKIS (affordable), (sustainable) and integrated. In addition, the implementation of quality control system and cost the local level and the system of supervision over the implementation of the compliance level also JKN-KIS in the area is no less important issue to be addressed by the Government area. ${ }^{5}$

The role of local government in this case the Health Department in the implementation of BPJS can be seen in the various legislations which include licensing, facilitator, or referrer. As a referrer, can be seen in Article 29 (1) of the President of the Republic of Indonesia Number 12 of 2013 on Health Insurance (Presidential Decree No. 12 of 2013) which states that for the first time each participant registered by BPJS on the first level health facilities BPJS determined by the recommendation of district health offices / city.

In Blora, emerging constraints in the regulation BPJS. For example, the achievement of universal health coverage universal health coverage (UHC) has not reached the target, where membership JKN-new KIS approximately $67.53 \% .^{6}$ It is a challenge for Blora Regency Health Bureau to improve BPJS role in the implementation of Health.

Based on the above background, the authors are interested in doing research on "The Role of Health Department of Blora Regency in Implementing BPJS Based on Act No. 40 of 2004 on National Social Security System To Improve Public Services "

\footnotetext{
5 Pentingnya Peran Pemda dalam Program JKN-KIS, (https://www.bpjs-kesehatan.go.id, Accessed October 7, 2019).

6 Pencapaian Target UHC BPJS Kesehatan Terkendala Faktor Kesadaran Masyarakat, https://pasfmpati.com, Accessed October 7, 2019).
} 
Based on the description of the background described above, then the problem is formulated as follows:

- What Is The Role of Health Department of Blora Regency in the Implementation of BPJS Based On Act No. 40 of 2004 on National Social Security System to Improve Health Services To The Society?

- What Are The Obstacles That Arise In The Implementation of BPJS in Blora and What's The Solution?

\section{Research Methods}

The approach used in this study is a sociological juridical approach, the research is based on the science of normative law (legislation), but instead examines the norm system observe how North reactions and interactions that occur when a system of norms that work in the society. ${ }^{7}$

Research is descriptive analytical specifications, which provide a clear, detailed and systematic. The data used are primary data and secondary data obtained through field studies and literature. The method of data analysis using qualitative analysis.

\section{Discussion}

\subsection{Blora Regency Health Office Role in Implementation of BPJS Based On Act No. 40 of 2004 on National Social Security System to Improve Health Care Society}

The government of Blora regency in order to improve people's health continues to perform health services thoroughly and evenly. Each stage of health development, announced by the government aimed to get closer and improve health services to the society. These programs are designed so that people can reach them easily, cheaply, and even free. ${ }^{8}$

Blora Regency Health Office was instrumental in implementing BPJS to improve public health services. In this case the Blora Regency Health has three key roles, namely: ${ }^{9}$

- As A Regulator

Health Department Blora should be a pioneer, locomotives, propulsion, institutions, most importantly, the best and most knowledgeable about health, as a role model, able, capable, proactive and referees are fair in the health care system in its territory, must provide the ground rules that its purpose is to ensure that the system can be run in a fair and protect the people to achieve optimal health status.

- As Funders

Government Blora through the Health Department must ensure that the health services needed by the society can be accessed by all the people, so if there is a barrier to the economy of the society is poor, then the Health Department Blora should spearhead and is responsible for providing funding and or make system so that health services are accessible to the poor with good quality;

\footnotetext{
7 Mukti Fajar ND dan Yulianto Achmad, 2012, Dualisme Penelitian Hukum Normatif dan Empiris, Yogyakarta : Pustaka Pelajar, h.47.

${ }^{8}$ The Central Bureau of Statitik Blora, 2019, Profil Kesehatan Kabupaten Blora 2018, BPS Blora, p.1

${ }^{9}$ Blora Regency Health Office, op.cit.
} 


\section{- As Executor}

Health Department Blora must be motivators, leaders, movers and institutions that become the foundation of the government of Blora in order to provide health care to people who are qualified, competent, capable and responsible through the Technical Services Unit Area (UPTD), namely (PHC; Warehouse Pharmacy, Health laboratory), and the health center; Rural Health Clinic (PKD) as well as referral services at the Regional Hospital of Blora and Cepu.

Based on the interview with Mr. L. Kristiawan, to carry out its role as a regulator in the Implementation of BPJS, Blora Regency Health Office has set some policies contained in the decree and the circular. On December 31, 2018, Blora Regency Health Office issued a circular regarding the invalidity of another Regional Health Insurance Card (Jamkesda) began in January 2019 in the district of Blora. This is because Jamkesda integrated into JKN KIS. ${ }^{10}$

To implement this policy, the District Health Office Blora, Central Java distribute cards National Health Insurance-Card Healthy Indonesia (JKN-KIS) in the clinic so that the poor people who used to be the participants of the Regional Health Insurance (Jamkesda) Blora Regency can get a card (JKN-KIS ) at a local clinic.

The Role of Health Department of Blora Regency in addition to the integration of Jamkesda to BPJS Health, also made a poor recommendation to take to BPJS. In this case the Blora Regency Health Office in coordination with the Social Office of Women's Empowerment and Child Protection (P3A) that holds data poor society data recorded by the statistical agency of Blora. Then the data is validated and the Health Department determined whether the public was entitled to receive assistance from contributions or premiums paid by the government and make recommendations on the poor to be brought to BPJS. Furthermore, Blora Regency Health Office provides to the Regent to set the participants Recipient Contribution (PBI) sourced health insurance budget. ${ }^{11}$

Other policies set by the Health Department of Blora is related to the supervision has strived to make policies related to the implementation of supervision in the implementation of BPJS. In this case the Blora Regency Health Office has set the Decree of the Head of Team Health Department Prevention of Fraud (Fraud) in the Implementation of the National Health Insurance Program in Healthcare Facilities Blora First Level Fiscal Year 2020. ${ }^{12}$

Blora Regency Health Office is also monitoring the administrative requirements of the health facility, for example, whether the Certificate Register (STR) nursing personnel are still active or not, whether the doctor who is already really having an SIP. The administrative requirements is a prerequisite for health facilities in collaboration with

\footnotetext{
${ }^{10}$ Results Interview with Mr. L. Kristiawan as the Head of Service and the Health Resources of Blora Regency Health Office, dated February 3, 2020.

11 Interview with Rudi Supranoto, as the Head of Health Office of Health Resources of Blora, dated February 3, 2020.

12 Results Interview with Mr. L. Kristiawan as the Head of Service and the Health Resources of Blora Regency Health Office, dated February 3, 2020
} 
BPJS. This is to support services at the health facilities in order to truly serve the participants well in BPJS. ${ }^{13}$

Blora Regency Health Office role in the implementation of BPJS also is as funders. In the budget provision for the fulfillment of the accreditation of health centers, Blora Regency Health Department to make recommendations to be budgeted in the budget. The budget process starts from collecting groove accreditation regulations related to accreditation, making the road map plan, then put RPJMD and sector plans which will be a work plan SKPD Work Plan and Budget, discussed in the parliament a new draft Regional Budget.

Blora Regency Health Office also provides recommendations to the Regent related to the determination of participants Recipient Contribution (PBI) sourced health insurance budget in fiscal year 2020 amounting to 55,000. Based on these recommendations, then Regent make its commencement letter. Thus Blora regency government to allocate funds to the Health Department to cover the financing of all participants PBI BPJS which will be budgeted in the budget. PBI funding needs in Blora proposed in the draft budget 2020 was Rp 30 Billion for 55 thousand of the poor, but in the discussion of the local budget approved in 2020 to Rp 22 billion.

Based on the description above can be seen that the Role of Health Department of Blora Regency in the implementation of BPJS is as a regulator, as executor and as funders. It is the mandate of Article 99 of Presidential Decree No. 82 of 2018 concerning stating the Health Insurance that the local government must support the implementation of the Health Insurance program. Such support is done through an increase in the attainment of membership, improving health services and other support legislation in order to ensure the sustainability of the Health Insurance program.

Besides the role of health authorities Blora also the implementation of the provisions of Article 14 paragraph (1) of Act No. 36 of 2009 on Health which states that the government is responsible to plan, organize, organize, develop, and oversee the implementation of health efforts equitable and affordable by the public. It is also in line with the mandate of Article 20 of the Act No. 36 of 2009 on Health which states that the government is responsible for the implementation of public health insurance through a national social security system for individual health efforts.

Based on the theory of roles as proposed Soerjono Soekanto, the role is a system of rules that contains benchmarks actions, in the positions specified in society, the position of which may belong to an individual or groups of personal involvement of the holders to fulfill that role, can match or maybe the opposite with what is specified in the rules. ${ }^{14}$

Based on this theory, then the Role of Health Department of Blora Regency in the implementation of BPJS a normative role and the role of the ideal, which is tailored to the implementation of the role of regulatory requirements predetermined. In this case the implementation of the Health Department's role is based on Act No. 40 of 2004 on

\footnotetext{
13 Results Interview with Mr. L. Kristiawan as the Head of Service and the Health Resources Blora Regency Health Office, dated February 3, 2020

${ }^{14}$ Soerjono Soekanto, 2003, Pokok-Pokok Sosiologi Hukum, Jakarta : Grafindo Persada, p.139
} 
National Social Security System which is then translated into various implementation regulations through Presidential Regulation nor Regulation of the Minister of Health. Judging from the theory of legal certainty, the Role of Health Department of Blora Regency has met the principle of legal certainty. Teachings of legal certainty derived from the juridical-dogmatic teachings, no legal purpose other than just ensure the realization legal certainty, Legal certainty is embodied by the laws of nature that just makes a common law rule. The general nature of the rule of law to prove that the law was not intended to bring about justice or expediency, but solely for certainty. ${ }^{15}$

Legal certainty is needed to ensure peace and order in the society because of the certainty of law (rules / regulations general) is coercive and applies to anyone. With the existence of clear rules related to the role of local governments in the implementation of Health BPJS, Blora Regency health department is working units authorized in the conduct BPJS in Blora regency.

\subsection{Emerging Obstacles in Implementation of BPJS in Blora and The Solutions}

Based on the results of research in Blora Regency Health Office, there are some obstacles in the Implementation of BPJS. This is as stated by Mr. Rudy Supranoto which states that in implementing BPJS in the District are still many obstacles. These barriers are: ${ }^{16}$

- The existence of several health facilities can not serve participants as yet accredited by BJPS

One health facilities namely PKU Muhammadiyah Hospital in Cepu, Blora Regency patient care pause Social Security Agency (BPJS) Health. This is because the future accreditation of PKU Muhammadiyah Hospital Cepu is up since January 26, 2019, so that after that date should have already received a license renewal of the accreditation.

To overcome these obstacles, the hospital returned apply for extension of accreditation to KARS returns filed in January 2019 , so it can be returned to serve the society of participants BPJS. In June, at the end of Muhammadiyah Hospital started serving patients Cepu Health Care Pro BPJS participants after the completion of a process of accreditation in the hospital.

- Health care quality is not maximized

The quality of health services in the area of Blora regency administration is still not optimal. It can be seen from a high rate of maternal and infant mortality is $14 \%$, there is still a lack of specialists in Blora, and many people who choose to hospitals outside the area for treatment. This indicates that the health service in Blora not maximized. To overcome these obstacles, Blora regency through the Health Department continues to work on improving the quality of healthcare in hospitals and health centers. In this case the Health Department has conducted training for health workers, but gradually and only a few workers only due to limited budget.

\footnotetext{
${ }^{15}$ Achmad Ali, 2002, Menguak Tabir Hukum (Suatu Kajian Filosofis dan Sosiologis), Gunung Agung, Jakarta, p. 82-83

${ }^{16}$ Interview with Mr. Rudy Supranoto as Head of Health Office of Health Resources of Blora, dated February 4, 2020.
} 
- Role in the implementation of the Health Service BPJS not maximized

The role of the health department in JKN era has had its legal basis, and have been several changes to the legal basis which has described the role of the Health Service to BPJS. Currently the health department to act more as a contractor in the purchasing system while the regulatory functions marginalized. In principle agent relationship, BPJS the Purchaser, related to the public as an agent of citizens, and connect with service providers as a principal, as well as acting as an agent appointed by the government. The government should play the role as a steward in addition to its role in providing funding, health services, and policy directions. At this time the Health Department's role in the era of JKN over to the supervisor, while related to its role as regulator is still weak.

To overcome these obstacles, the need for regulations that could give a strong role to the district health office so that not only the "contractor" but as a regulator.

\section{Closing}

\subsection{Conclusion}

- The Role of Health Department of Blora Regency in the Implementation of BPJS Based On Act No. 40 of 2004 on National Social Security System to improve service to the public is as regulators, implementers and donors.

- The obstacles that arise in the implementation of BPJS in Blora is the health facilities that serve the participants could not BJPS Health because it has not been accredited. As the solution is health facility shall submit the extension of accreditation to KARS. Obstacles in the implementation of the Health Service BPJS not maximized due to existing regulations make the Health Department as a contractor and not as regulator. It required legislation and regulations for strengthening the role of the Health Department as a regulator.

\subsection{Suggestion}

- For local government of Blora Regency should provide a sufficient budget to meet the health care needs of the poor

- For the Health Department, the need for strengthening the role in the implementation of BPJS.

\section{References}

\section{Book}

[1] Achmad Ali, 2002, Menguak Tabir Hukum (Suatu Kajian Filosofis dan Sosiologis), Gunung Agung, Jakarta

[2] Badan Pusat Statitik Kabupaten Blora, 2019, Profil Kesehatan Kabupaten Blora 2018, BPS Kabupaten Blora.

[3] Mukti Fajar ND dan Yulianto Achmad, 2012, Dualisme Penelitian Hukum Normatif dan Empiris, Yogyakarta : Pustaka Pelajar 
[4] Soerjono Soekanto, 2003, Pokok-Pokok Sosiologi Hukum, Jakarta : Grafindo Persada.

[5] Yohandarwati dkk, 2003, Sistem Perlindungan dan jaminan Sosial (Suatu Kajian Awal), Bappenas, Jakarta.

\section{Laws and regulations}

[1] Constitution of the Republic of Indonesia 1945.

[2] Act No. 40 of 2004 on National Social Security System.

[3] Indonesian Presidential Regulation No. 12 of 2013 on Health Insurance.

\section{Website}

[1] Pentingnya Peran Pemda dalam Program JKN-KIS, (https://www.bpjskesehatan.go.id, Accessed October 7, 2019).

[2] Pencapaian Target UHC BPJS Kesehatan Terkendala Faktor Kesadaran Masyarakat, (https://pasfmpati.com, Accessed October 7, 2019). 